\title{
Configurações
}

configurações

Revista de sociologia

\section{Género e gerações}

\section{Nota prévia}

\section{Manuel Carlos Silva}

\section{OpenEdition \\ Journals}

\section{Edição electrónica}

URL: http://journals.openedition.org/configuracoes/269

DOI: 10.4000/configuracoes.269

ISSN: 2182-7419

\section{Editora}

Centro de Investigação em Ciências Sociais

\section{Edição impressa}

Data de publição: 1 janeiro 2008

Paginação: 5-6

ISSN: 1646-5075

\section{Refêrencia eletrónica}

Manuel Carlos Silva, « Nota prévia », Configurações [Online], 4 | 2008, posto online no dia 12 fevereiro

2012, consultado o 22 setembro 2020. URL : http://journals.openedition.org/configuracoes/269 ;

DOI : https://doi.org/10.4000/configuracoes.269

Este documento foi criado de forma automática no dia 22 setembro 2020.

(c) CICS 


\title{
Nota prévia
}

\author{
Manuel Carlos Silva
}

1 Este número da revista Configurações é igualmente um número temático que se centra sobre a família, a população, as gerações e o género, com particular destaque para estes dois últimos tópicos. Enquadrado este número no grupo de trabalho "Família, saúde e solidariedade", a sua organização esteve a cargo da colega Alice Delerue Matos e do colega Victor Terças Rodrigues, a quem aproveito para agradecer.

Datado de 2008, também este número surge com certo atraso para o que, além de outros factores, concorre o facto de ser um número temático. Estamos determinados e convictos de que em breve poderá ser editado um próximo número intertemático, o qual, a julgar pelos artigos enviados e já avaliados, será um número duplo, que contribuirá para a recuperação do atraso, retomando assim a regularidade temporal da revista.

3 O Centro de Investigação em Ciências Sociais (CICS), enquanto principal suporte organizativo da edição da revista financiada pelas verbas da FCT, tendo em conta as sugestões do painel de avaliação acerca desta unidade de investigação, levou a cabo uma ligeira reestruturação das linhas de investigação e seus respectivos grupos de trabalho.

4 Após alguns meses de debate e maturação da decisão, foram aprovados pela Comissão Científica do CICS e aceites pela FCT os seguintes grupos: (i) cultura, ciência e identidades; (ii) território, desenvolvimento e organizações; (iii) trabalho, desigualdades sociais e políticas públicas; (iv) população, família e saúde. É agora necessário completar alguns trâmites a nível interno, de modo a que certas propostas sejam apreciadas pelos respectivos órgãos, aliás em conformidade com as alterações em curso na Universidade do Minho a nível institucional, estatutário e regulamentar.

5 Os temas deste número, designadamente o género e as relações intergeracionais, são de extrema actualidade, bem presentes nos mais diversos congressos e colóquios, mas nem por isso dispensam um aprofundamento e uma abordagem plural e multidimensional. 
6 Sendo objecto de vários olhares e disciplinas científicas, estes temas são também neste número, como o próprio subtítulo da revista sugere, tratados mormente numa perspectiva sociológica.

7 A colega Alice Matos, coordenadora deste número, encarregou-se de fazer uma primeira síntese e comentário ao conteúdo de cada um dos artigos, dispensando-me de me debruçar sobre estes. Em todo o caso, permitam-me que destaque o valor dos relevantes contributos dos vários colegas sobre estes temas, o que enriquecerá certamente o património dos estudos sobre as identidades geracionais e de género, suas regularidades e transformações de acordo com os tempos do ciclo de vida.

8 É devida uma palavra de profundo pesar pelo falecimento de Maria Joannis Baganha, nossa amiga e colega da Universidade de Coimbra - e, anteriormente, entre 1990 e 1991, nossa colega na Universidade do Minho. Tendo colaborado com esfusiante entusiasmo em várias iniciativas do ICS, do Departamento de Sociologia e, posteriormente, do CICS, nomeadamente com um capítulo sobre migrantes do Leste na publicação resultante do Colóquio sobre Nação e Estado, aceitou integrar o Conselho Consultivo da Revista Configurações. A sua figura intelectual e a sua obra, enquanto socióloga e cidadã, deixaram marcas indeléveis que merecem a nossa gratidão e singela homenagem.

9 Por fim, uma palavra de agradecimento aos autores que se dignaram submeter à apreciação do CICS os artigos para publicação na revista Configurações, cujo valor foi certificado pelos próprios revisores e avaliadores internos e externos.

\section{AUTOR}

\section{MANUEL CARLOS SILVA}

Director do CICS 